\title{
Pola Bakteriologis dan Uji Sensitivitas pada Sepsis Neonatorum Awitan Dini
}

\author{
Mayetti, Ied Imilda \\ Departemen Ilmu Kesehatan Anak, Fakultas Kedokteran Universitas Andalas, RSUP Dr. M. Djamil \\ Padang
}

\begin{abstract}
Latar belakang. Insidens sepsis neonatorum di negara berkembang masih tinggi sekitar (1,8-18/1000). Diagnosis dan tata laksana dini sangat penting dalam menurunkan angka kesakitan dan kematian pada neonatus.

Tujuan. Mengetahui insidens sepsis neonatorum, bakteri penyebab serta sensitivititas dari antibiotik yang digunakan.

Metode. Penelitian retrospektif pada neonatus yang dirawat di Ruang Perinatologi Risiko Tinggi (Peristi) level II RSUP Dr. M. Djamil Padang, 1 Januari sampai 30 Juni 2009. Subjek penelitian adalah semua neonatus dengan sepsis neonatorum awitan dini disertai biakan darah positif. Kriteria eksklusi apabila data rekam medis tidak lengkap.

Hasil. Terdapat 53 neonatus yang didiagnosis sepsis neonatorum dini dengan biakan darah yang positif. Staphylococcus aureus (32,6\%) merupakan penyebab yang terbanyak diikuti oleh Klebsiella sp dan Enterobacter $s p$ (masing-masing 22,6\%). Sulbactam-sefoperazon dan meropenem merupakan antibiotik yang paling sensitif terhadap mikroorganisme tersebut.

Kesimpulan. Bakteri terbanyak penyebab sepsis awitan dini pada 13 neonatus adalah Staphylococcus aureus. Sulbactam-sefoperazon dan meropenem merupakan antibiotik paling sensitif. (Sari Pediatri 2010;11(5):326-9).
\end{abstract}

Kata kunci: sepsis neonatal, bakteri penyebab, antibiotik.

Telah dipresentasikan pada Kongres Nasional X PERINASIA di Balikpapan, 5-7 November 2009.

\section{Alamat korespondensi:}

Dr. Mayetti SpA. Sub Bagian Pediatrik Gawat Darurat. Bagian Ilmu Kesehatan Anak Fakultas Kedokteran Universitas Andalas-RS Dr. M. Djamil. Jl Perintis Kemerdekaan, Padang. Telepon: 0751-37913. Fax.0751-811179

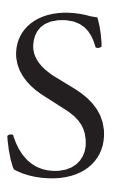

epsis merupakan salah satu penyebab kematian terbanyak pada neonatus. Di negara maju angka kejadiannya sekitar 3 per 1000 kelahiran hidup dengan angka kematian 10,3\%, sedangkan di negara sedang berkembang angka kejadian sepsis lebih tinggi yaitu 1,8-18 per 1000 kelahiran hidup dengan angka kematian 12\%-68\%. ${ }^{1,2}$ Sepsis neonatorum adalah sindrom klinis dengan gejala infeksi sistemik dan diikuti dengan bakteremia, yang terjadi pada bulan 
Mayetti dkk: Bakteriologis dan uji sensitivitas sepsis neonatorum awitan dini

pertama kehidupan (neonatus). ${ }^{3}$ Tata laksana sepsis, khususnya pilihan antibiotik seharusnya didasarkan pada bakteri penyebab infeksi yang diperoleh dari biakan darah dan hasil uji sensitivitas antibiotik terhadap bakteri tersebut. Namun karena pemeriksaan biakan bakteri dan uji sensitivitas membutuhkan waktu yang cukup lama (48-72 jam). Pada sepsis neonatorum antibiotik harus diberikan sesegera mungkin, maka sebaiknya diketahui pola kuman penyebab sepsis di ruang perawatan neonatus sebagai pedoman pemberian antibiotik empris tanpa menunggu hasil kultur dan uji sensitivitas. ${ }^{4,5}$

Di Bagian Peristi level II RS Dr. M. Djamil Padang, sampai saat ini masih digunakan ampisilin dan gentamisin sebagai lini pertama dalam penanganan sepsis neonatorum. Penelitian bertujuan untuk mencari bakteri penyebab sepsis pada neonatus serta mengetahui tingkat sensitivitas antibiotik terhadap mikroorganisme tersebut, khususnya pada sepsis awitan dini (SAD).

\section{Metode}

Penelitian cross-sectional dilakukan secara retrospektif, data rekam medis neonatus yang dirawat di Ruang Peristi level II RS Dr. M. Djamil Padang, pada 1 Januari sampai 30 Juni 2009. Subjek penelitian adalah semua neonatus dengan sepsis neonatorum awitan dini. Sepsis awitan dini (SAD) adalah sepsis yang terjadi dalam 72 jam pertama kehidupan. Neonatus yang diikutkan dalam penelitian ini adalah semua neonatus dengan gejala klinis sepsis dan biakan darah positif. Kriteria eksklusi apabila data rekam medis tidak lengkap.

\section{Hasil}

Limaratus neonatus telah dirawat di Ruang Peristi level II RS Dr. M. Djamil Padang periode 1 Januari
Tabel 1. Mikroorganisme pada biakan darah $(\mathrm{n}=53)$

\begin{tabular}{lc}
\hline Jenis mikroorganisme & Jumlah \\
\hline Staphylococcus aureus & 16 \\
Klebsiella spesies & 12 \\
Enterobacter spesies & 12 \\
Staphylococcus epidermidis & 6 \\
Pseudomonas aerugenosa & 2 \\
Citobacter & 2 \\
Serratia mescescen & 2 \\
Candida spesies & 1 \\
\hline
\end{tabular}

- 30 Juni 2009. Enam puluh sembilan neonatus dirawat dengan diagnosis sepsis neonatorum awitan dini, sedangkan yang memenuhi kriteria penelitian 53 neonatus Berdasarkan hasil penelitian, bakteri terbanyak penyebab sepsis adalah Staphylococcus aureus $(30,2 \%)$ diikuti oleh Klebsiella sp dan Enterobacter sp (masing-masing 22,6\%). Jumlah bakteri penyebab sepsis yang lain, Pseudomonas aeruginosa, Cilobacter, Serratia mescescen dan Candida spesies hanya berkisar antara 1,9\%-3,8\% (Tabel 1).

Netilmisin merupakan antibiotik yang paling sensitif $(37,5 \%)$, terhadap bakteri penyebab SAD terbanyak (Staphylococcus aureus), diikuti sulbactam sefoperazon $(31,2 \%)$ dan ampisilin (25\%). Ampisilin dan gentamisin memiliki sensitivitas yang rendah $(18,7 \%)$ terhadap Staphylococcus aureus.

Sulbactam sefoperazon merupakan antibiotik paling sensitif terhadap bakteri peringkat dua terbanyak penyebab sepsis (Klebsiella $s p$ ), diikuti oleh meropenem dan siprofloksasin. Sementara ampisilin dan gentamisin mempunyai sensitivitas yang rendah terhadap bakteri ini. Meropenem sebagai antibiotik dengan sensitivitas tertinggi terhadap bakteri penyebab sepsis peringkat ketiga terbanyak (Enterobacter $s p$ ) diikuti oleh sulbactam sefoperazon dan siprofloksasin. Ampisilin dan gentamisin mempunyai tingkat sensitivitas yang rendah.

Berdasarkan jumlah kasus, Sulbactam-sefoperazon

Tabel 2. Sensitivitas antibiotik terhadap tiga jenis bakteri terbanyak penyebab sepsis neonatorum

\begin{tabular}{lccccc}
\hline Bakteri Penyebab & $\begin{array}{c}\text { Sulbactam } \\
\text { sefoperazon }\end{array}$ & Meropenem & Netilmisin & Ampisilin & Gentamisin \\
\hline Staphylococcus aureus & 5 & 3 & 6 & 4 & 3 \\
Klebsiella sp & 9 & 7 & - & 1 & 1 \\
Enterobacter $s p$ & 9 & 10 & - & 2 & 2 \\
\hline
\end{tabular}


mempunyai sensitivitas yang tinggi dibandingkan antibiotik yang lain terhadap ketiga jenis kuman terbanyak penyebab sepsis, diikuti oleh meropenem. Ampisilin mempunyai sensitivitas yang jauh lebih rendah, hanya memperlihatkan sensitivitas pada tujuh kasus, demikian juga dengan gentamisin (enam kasus). Sementara netilmisin hanya sensitif terhadap Staphylococcus aureus (Tabel 2).

\section{Diskusi}

Bakteri penyebab sepsis neonatal awitan dini (SAD) terbanyak adalah Staphylococcus aureus diikuti Klebsiella sp dan Enterobacter sp. Hasil yang sama dilaporkan oleh Wilar R, Susanto F ${ }^{6}$ di RS Kandou Manado periode Juli-Desember 2007, Staphylococucs aureus sebagai bakteri terbanyak penyebab sepsis neonatorum. World Health Organization Young Infants Study Group pada tahun $1999^{7}$ juga menemukan Staphylococcus aureus (23\%) sebagai bakteri terbanyak yang ditemukan pada biakan darah di empat negara sedang berkembang (Ethiopia, Philipina, Papua New Guinea, dan Gambia). Sedangkan Divisi Perinatologi Departemen Ilmu Kesehatan Anak FKUI-RSCM pada bulan Juli 2004-Mei 2005 mendapatkan Staphylococcus sp 6,8\% setelah Acinetobacter calcoacetius (35,67\%), diikuti Enterobacter sp (7,01\%). ${ }^{4}$ Di negara maju ditemukan hasil yang berbeda. Bakteri penyebab terbanyak penyebab SAD adalah Streptococcus grup $B$ (>40\% kasus), Escherichia coli, Haemophilus influenza dan Listeria monocytogenes. ${ }^{8}$

Dari hasil uji sensitivitas terhadap bakteri terbanyak penyebab SAD (Staphylococcus aureus) antibiotik yang mempunyai sensitivitas tertinggi adalah netilmisin, diikuti sulbactam sefoperazon dan ampisilin. Uji sensitivitas terhadap bakteri penyebab sepsis peringkat dua terbanyak (Klebsiella sp), sulbactam sefoperazon sebagai antibiotik paling sensitif, diikuti oleh meropenem dan siprofloksasin. Sementara hasil tertinggi pada uji sensitivitas terhadap Enterobacter $s p$ adalah meropenem diikuti oleh sulbactam sefoperazon dan siprofloksasin.

Berdasarkan jumlah kasus, sulbactam sefoperazone mempunyai sensitivitas yang tinggi dibandingkan antibiotik yang lain terhadap ketiga jenis kuman terbanyak penyebab sepsis, diikuti oleh meropenem, ampisilin, dan gentamisin. Sementara netilmisin tidak dapat digunakan pada ketiga bakteri

\section{Kesimpulan}

Selama periode Januari - Juni 2009 telah dirawat 53 bayi sepsis neonatorum awitan dini. Bakteri terbanyak sebagai penyebab SAD adalah Staphylococcus aureus, diikuti oleh Klebsiella sp dan Enterobacter sp. Antibiotik yang paling sensitif untuk Staphylococcus aureus adalah netilmisin diikuti sulbactam sefoperazone dan ampisilin. Sementara antibiotik paling sensitif untuk Klebsiella $s p$ adalah sulbactam sefoperazon, meropenem, dan siprofloksasin serta antibiotik paling sensitif untuk Enterobacter sp adalah meropenem, sulbactam sefoperazon, dan siprofloksasin. Sulbactamsefoperazon dan meropenem mempunyai tingkat sensitivitas yang tinggi terhadap kuman terbanyak penyebab sepsis di ruang peristi level II RS Dr. M. Djamil Padang, melebihi sensitivitas dari antibiotik lini pertama yang biasa digunakan, yaitu ampisilin dan gentamisin. Perlu dievaluasi untuk mengganti jenis antibiotik digunakan sebagai lini pertama dalam pengobatan sepsis neonatorum awitan dini di Ruang Peristi level II RS Dr. M. Djamil Padang, yaitu Ampisilin dan Gentamisin menjadi sulbactam sefoperazon atau meropenem.

\section{Daftar Pustaka}

1. Shattuck KE, Chonmaitree T. The changing spectrum of neonatal meningitis over a fifteen-year period. Clin Pediatr 1992;31:130-6.

2. Watson RS, Carcillo JA, Linde-Zwirble WT, Clermont G, lidicker J. The epidemiology of severe sepsis in children in the United States. Am J Respir Care Med 2003; 167:695-701.

3. Remington, Klein. Bacterial sepsis and meningitis. Dalam: Infectious diseases of the fetus and newborn, infant. Edisi ke-4. Philadelphia: WB Saunders; 1995.h. 836-90.

4. Aminullah A. Masalah terkini sepsis neonatorum. Dalam: Update in neonatal infection. Departemen Ilmu Kesehatan Anak FKUI-RSCM : 2005.h.1-15.

5. Rohsiswatmo R. Kontroversi diagnosis sepsis neonatorum. Dalam: Update in neonatal infection. Departemen Ilmu Kesehatan Anak FKUI-RSCM; 2005.h. 32-43.

6. Wilar R, Susanto F. The bacterial agent profile of sepsis neonatorum in July - December 2007 at Kandou Hospital. Dalam: 14th Indonesian Congress of Pediatrics. 
Surabaya: Indonesian Pediatrics Society, 2008.

7. Osrin D, Vergnano S, Costello A. Serious bacterial infections in newborn infants in developing countries. Curr Opin Infect Dis 2004;17:217-24.
8. Speck WT, Aronoff SC, Fanaroff AA. Neonatal infections. Dalam: Klaus MH, Fanaroff AA, penyunting. Care of the high risk neonates. Edisi ke-3. Philadelphia: WB Saunders; 1986.h. 262-85. 